\title{
EFFECT OF GAS FLARING ON PLANTS IN A TROPICAL FRESH WATER SWAMP FOREST IN NIGERIA
}

\author{
L. A. Daniel-Kalio and S. A. Braide \\ (L.A.D-K.: Department of Applied and Environmental Biology, Rivers State University of Science \\ and Technology, Diobu, Port Harcourt, Nigeria; S.A.B.: Institute of Pollution Studies, Rivers State \\ University of Science and Technology, Nkpolu-Oroworukwo, Port Harcourt, Nigeria)
}

\begin{abstract}
An oil field in a fresh water swamp forest was visited during the wet and dry seasons to assess the impact of gas flaring on vegetation in the area. Gas flaring attracts yam beetles (Heteroligus spp.) and grasshopper (Zonocerus variegates) to the area, and these attack crops. Generally, the nearer plantain (Musa sp.) and oil palm (Elaeis guineensis) are to gas flare, the poorer is their plant aspect (i.e. general appearance). At the control site, some $45 \mathrm{~km}$ away from the flare site, plant aspect was good for plantain and oil palm, and very good for mango (Mangifera indica) and bamboo (Bambusa vulgaris). Bamboo, a graminaceous plant appears tolerant to gas flaring, and thrives well in the area. Sooty mould (Meliola sp.) incidence on sweet orange (Citrus sinensis) is higher during the dry season than during the wet season, and also higher when located close to gas flares than when further away. Gas flaring in the area tends to promote sooty mould incidence. Reasons have been presented to explain these observations.
\end{abstract}

\section{Résumé}

Lloyd A. D.-K. \& Braide S. A.: Effet de dégagement des gaz sur les plantes dans une forêst tropicale inondable d'eau douce au Nigéria. Un gisement pétrolifère dans une forêt inondable d'eau douce était inspecté pendant les saisons des pluies et sèches pour évaluer l'impact de dégagement des gaz sur la végétation de l' environnement. Le dégagement des gaz attire les coléoptères (Heteroligus spp.) et la sauterelle (Zonocerus variegatus) à l'environnement et ces attaquent les cultures. Dans l'ensemble, plus le plantain (Musa sp.) et le palmier (Elaeis guineensis) sont proches au dégage des gaz, plus sont faibles leurs aspects de plante (c. -à - d. apparence générale). Au site de contrôle, quelques $45 \mathrm{~km}$ loin du site de dégage, aspect de plante était élevé pour le plantain et le palmier, et plus élevé pour le manguier (Mangifera indica) et le bambou (Bambusa vlgaris). Le bambou, une plante graminacée semble tolérante au dégagement des gaz et pousse bien dans l'environnement. Le terreau de suie (Meliola sp.) une fréquence sur l'orange douce (Citrus sinensis) est plus élevé pendant la saison sèche que pendant la saison des pluies, et encore plus élevé lorsqu' elle se trouve prè de dégage des gaz que lorsqu'elle est plus éloignée. Le dégagement des gaz à l'environnement a la tendance de favoriser la fréquence de terreau de suie. Des raisons ont été présentées dans l'œuvre pour expliquer ces observations.

Nigeria have more than 60 oil fields. Each oil field has a flow station with a gas flare site. A gas flare site may have a number of stacks depending on the size of the flow station. Some of the stacks are vertical, while others are horizontal, all of them flaring gas into the atmosphere.

Concerning gas flaring in Nigeria, Moffat \& Linden (1995) stated that as a by-product of oil production, Nigeria flares more gas than any other country in the world, most of it from the Niger Delta; about 88 per cent of the associated gas is oil in it, there has been no systematic attempt to explore natural gas. Oil operating companies in 
flared. They also stated that in 1994, the total emission of $\mathrm{CO}_{2}$ from gas flaring in the Niger Delta amounted to an estimated 35 million tons $\mathrm{yr}^{-1}$. Considering the low combustion efficiency of Nigerian flares, which they put at 80 per cent, a large portion of the gas is vented mainly as methane. For Rivers (including Baylesa) and Delta States in Nigeria, around 12 million tons of methane are released into the atmosphere per year. They came to the conclusion that as a result of the much higher global warming potential of methane (64 vs 1 for $\mathrm{CO}_{2}$ ) the significance of the Nigerian gas flares is considerable.

Anderson (1996), expressing similar views in a keynote address, stated that the disposal of associated gas (AG) has been a major challenge for the Nigerian oil and gas industry, as Nigeria has become the greatest gas flaring country in the world. According to him, roughly 1000 standard cubic feet (scf) of gas is produced in Nigeria with every barrel of oil. Hence, with oil production of about 2.0 million barrel per day (b/d), some 2.0 billion scf of AG is produced every day, most of which is flared because of lack of commercial outlets.

Many investigators have studied the direct impact of air pollutants on vegetation. Odu, Adedipe $\&$ Spiff (1976), carrying out investigations on the environmental effects of Agip Oil Company flares on soils and crop production, reported that plants such as okro (Abelmoschus esculentus (L.) Moench), cowpea (Vigna unguiculata (L.)) and maize (Zea mays (L.)) were adversely affected, and that this was very serious near the flares. They also felt that these findings are generally applicable to gas flares. Last, Fowler \& Freer-Smith (1985) reported that damage to crops by high levels of air pollutants in industrial areas has often been reported but that now they have evidence that even lower levels of pollutants may reduce yields without causing recognizable lesions to the plants.

Ukegbu \& Okeke (1987), studying the effects of the Ashland Oil (Nigeria) Company on the yield and productivity of okro, maize and cassava
(Manihot esculenta Crantz) found that the impact was about 100 per cent loss in yield in all crops cultivated about $200 \mathrm{~m}$ away, 45 per cent loss for those about $600 \mathrm{~m}$ away and about 10 per cent loss in yield for crops about $1000 \mathrm{~m}$ away from the flare. They also attributed the no yield situation of crops cultivated in farms located about $200 \mathrm{~m}$ away from the flare to high temperature and radiation intensity characteristics.

Dosumu \& Amadi (1996), carrying out an extensive evaluation of impact of gas flare on maize and soya bean (Glycine $\max$ (L.) Mey) at the Izombe Flow Station, found that the productivity of crops decreased from 100 per cent to 10 per cent or less, as one moves further away from the flare station.

Other researchers have studied predisposition of plants by air pollutants. Chappelka \& FreerSmith (1995) reported that though air pollution can cause visible injury to foliage and a discruption of physiological processes, such as photosynthesis and carbon allocation, leading to losses in growth and productivity, yet of equal or greater importance is the potential of air pollutants to indirectly affect tree growth and vitality by predisposing them to injury from other abiotic and biotic stresses. They stated that air pollutants, such as $\mathrm{SO}_{2}, \mathrm{O}_{3}$ and acidic mists have been implicated as predisposing agents, rendering plants to become more susceptible to low temperature and low soil moisture stresses.

On plant tolerance to air pollutants, the Research and Monitoring Co-ordinating Committee (RMCC) of Canada (1990), in their long range transport of air pollutants and acid deposition assessment report, stated that nine hardwood tree species in Ontario differed in their susceptibility to air pollutants. Because of several reports and complaints of adverse effects of gas flare on surrounding vegetation (including crops), it was decided, as part of a general survey, to carry out field observational studies in order to ascertain the following:

1) The likely effects of gas flare on surround- 
ing vegetation;

2) The effect of distance from gas flare site on the plant aspect of selected crops and plants found in the area; and

3) The effect of the interaction of distance from gas flare and season on plant disease severity of selected plants.

The justification for such studies lies in the fact that they could provide information on the following:

a) Plant species that are tolerant to gas flare radiations and so can be used as heat brakers;

b) Whether gas flares can predispose plants to enhanced disease severity; and

c) Safety distances from gas flare sites for the cultivation of crops.

Such information can be used to formulate policies aimed at protecting farmers's crops and so reduce tension and hostilities between oil operators and their stake holding communities.

\section{Experimental}

For the purpose of the study, an oil field (Fig. 1), located within latitude $150000 \mathrm{~N}$ and $200000 \mathrm{~N}$ and longitude $450000 \mathrm{E}$ and $500000 \mathrm{E}$ in a tropical fresh water environment in Nigeria, was visited in the rainy season in August 1996 and in the dry season in March 1997. Two approaches were employed in the field work. The first was to assemble and interview some of the knowledgeable inhabitants of the area to find out their perceptions concerning the effects of gas flaring on surrounding vegetation. Where they alleged that damage to crops was as a result of gas flaring, they were asked to show proofs. A sample of the questionnaire used to obtain the farmers' perception is given in Appendix 1. The second phase of the field study was to visit the farms and make an independent and abjective assessment of gas flare effects on surrounding vegetation.

The main cultivated field crops in the area were yam (Dioscorea rotundata), cassava (Manihot exculenta) and rice (Oryza sativa). Yam is inter- cropped with maize (Zea mays), melon (Cucumeropus edulis), okro (Abelmoschus esculentus), fluted pumpkin (Telfairia occidentalis), and cocoyam (Colocasia esculenta and Xanthosoma sagittifolium). Cassava was intercropped with maize, fluted pumpkin and cocoyam. Rice was grown as a sole crop. The main homestead plants found in the area were mango (Mangifera indica), plantain (Musa sp.), sweet orange (Citrus sinensis) and pepper (Capsicum annиum). Other plants that were common in the area, and which in some places occurred at high densities were oil palm (Elaeis guineensis), bamboo (Bambusa vulgaris) and grasses.

Homestead farms, field farms and naturally growing bamboos were studied. Assessment of disease severity, based mainly on visible symptoms, were taken at six different locations, namely north-east, east, south, south-west and north-west, relative to the location of the three gas flare stacks operating in the area. At each cardinal position, assessments were made at various distances from the gas flare site, ranging from $100 \mathrm{~m}$ to $2500 \mathrm{~m}$. Another location, some $45 \mathrm{~km}$ away from the gas flare site, was used as control. These various distances constitute a factor, and the seasons (wet and dry), during which assessments were made, constitute another factor. Due to ease of accessibility the NE and $\mathrm{E}$ were studied in greater details.

Plant disease severity and insect infestation based on visible symptoms such as leaf chlorosis, yellowing and scorching of leaves, dehydration of plants, stunted plant growth and dying of plants were scored on a 0 - 6 assessment scale: 0 being no disease (or pest) incidence and 6 being more than 95-100 per cent incidence, occasioning the dying or death of plants. The 0-6 assessment scale used is a slight modification of that cited by Wheeler (1976) for potato blight and for tomato leaf mould (Wheeler, 1978). Data collected were converted to percentages before carrying out statistical analysis.

Another character assessed was plant aspect (i.e. the general appearance of all the aerial parts 
of the plant population in a location). For this, a 15 assessment scale was used as follows: $5=$ Very good, 4 = Good, 3 = Fair, 2 = Poor, and 1 = Very poor.

For each crop or plant, plant aspect readings obtained at various distances from the gas flare site were used to assess gas flare effects. The basis was that, to a certain limit, the nearer a plant species was to the gas flare, the greater would be the impact of the gas flare on that species. The access road to the flow station was used as one of the transects. At each sampling location and for each season, four areas were taken at random and scored for disease incidence or plant aspect. Generally, less than 5 per cent of the finite plant population was sampled. Where disease incidence ratings were taken for different crops or plants at the same location, and for two seasons, the disease incidences were compared both within a season and between seasons so as to make appropriate tentative inferences. The statistical analysis used was that described for simple random sampling for finite populations by both Snedecor \& Cochran (1980) and Steel \& Torrie (1980). Before analysis, the data on bamboo/chlorosis scores were transformed, using the square root transformation as described by Gomez \& Gomez (1984). Likewise, data on sweet orange/sooty mould scores were arcsin transformed according to the method of Gomez \& Gomez (1984).

\section{Results and discussion}

Farmer's perception of the effects of gas flaring on their major crops is presented in Table 1. Generally, the farmers believed that without gas flaring in the area, they could at least double their present crop yields because what they were getting before the flaring of gas in the area was more than twice their present output. Given the increased temperature, continuous lighting and gas emission from gas flaring in the area, the farmers' major complaints cannot be easily ignored. Crops require optimum temperature, light and clean air quality in order to express their potentialities (Walker, 1975). When these environmental requirements are grossly interfered with, there can be yield reductions even in the absence of other visible symptoms. Field verification of the effect of gas flare on crops in the area is presented in Table 2.

Increase in sooty mould incidence, severe yellowing, death of plants, increased pest incidence and enhanced weed competition were observed in the areas that are under the influence of gas flaring on the crops and plants listed against them. These effects caused by gas flaring were not observed at the control site, which was located about $45 \mathrm{~km}$ away. The effect of gas flares on plants may not only be direct. So, yield reduction in crops is

TABLE 1

Farmers' perception of the effect of gas flaring on their crops

\begin{tabular}{ll}
\hline Crop & Nature of problem attributed to gas flaring by farmers at Akri \\
\hline Yam $($ D. rotundata $)$ & $\begin{array}{l}\text { Gas flare }(\mathrm{GF}) \text { continuously emitting heat radiation, light and unburnt gas } \\
\text { drastically reduces yield, both quantitatively and qualitatively. GF attracts insects, } \\
\text { such as variegated grasshopper (Zonocerus variegates) that eats up vines, and } \\
\text { yam beetle (Heteroligus spp.) that attacks yam tubers. }\end{array}$ \\
Gassava $(M$. esculenta $)$ & GF attracts grasshoppers, which eat up the plants \\
Rice $(O$. sativa $)$ & No gas flare effect on rice was reported. \\
Mango $(M$. indica $)$ & $\begin{array}{l}\text { GF causes premature ripening of fruits, especially during the dry season months } \\
\text { of December-March each year. }\end{array}$ \\
Sweet orange $(C$. sinensis $)$ & $\begin{array}{l}\text { GF effect is similar to that of mango. In addition farmers believe that toxic } \\
\text { effluents dispersed by flood water to homes and farms adversely affect the crop. }\end{array}$
\end{tabular}


TABLE 2

Field verification of effects of gas flaring in the study area during the wet and dry seasons*

\begin{tabular}{lll}
\hline Likely effect due to GF & Nature of problem and crops affected \\
\hline $\begin{array}{l}\text { 1. } \\
\text { Increased sooty mould (Meliola } \\
\text { mangiferae) incidence }\end{array}$ & $\begin{array}{l}\text { The Meliola sp. is a saprophytic fungus that forms sooty mould } \\
\text { on both surfaces of plant leaves. It occurs heavily on mango, } \\
\text { sweet orange, lime (Citrus aurantifolia), bitter leaf (Vernonia } \\
\text { amygdalina) and pepper (Capsicum frutescens). High incidence } \\
\text { can reduce photosynthesis. }\end{array}$ \\
\hline 2. & Severe yellowing and death of plants & $\begin{array}{l}\text { The causative agents appear complex: plantain, pepper and, } \\
\text { particularly, sweet orange are very susceptible. }\end{array}$ \\
\hline 3. & $\begin{array}{l}\text { Increased pest incidence (Heteroligus } \\
\text { spp. and Z. varietgates) }\end{array}$ & $\begin{array}{l}\text { At our demand, we were shown a handful of yam beetles } \\
\text { (Heteroligus sp.) and some variegatus grasshopper. They also } \\
\text { showed us harvested yam tubers full of pot-holes from beetle } \\
\text { attack. }\end{array}$ \\
\hline $\begin{array}{l}\text { Enhanced weed competition from } \\
\text { e.g. signal grass (Bracharia deflexa) and } \\
\text { dayflower (Commelina benghalensis) }\end{array}$ & $\begin{array}{l}\text { Graminaceous plants like rice, bamboo and signal grass seem to } \\
\text { thrive well in the area. }\end{array}$ \\
\hline
\end{tabular}

* Gas flaring has been going on continuously in the study area for years. A number of the plants studied, such as mango, sweet orange, lime, bamboo, weeds, plantain and C. frutescens are perennial plants subjected continuously to gas flaring over the years.

likely to be the result of complex of factors, both direct and indirect. For example, the causative agents of severe yellowing and death of plantain, pepper and sweet orange in the area appear to be complex. This is because the area experiences annual floodings. However, in 1988 and 1994, prior to the field studies, flooding was particulary severe. There were also uncovered waste pits in the area, receiving liquid effluents from flow station activities. When heavy flooding occurs, these waste pits are inundated and their contents are distributed to farms and homes in floodwater, destroying crops and houses and reducing thousands of farmers to instant penury. In 1995, an oil blowout occurred in the area, followed by a heavy annual flooding.

Diseases and pests in the area appear to be unusually high. Weeds tend to thrive very well. These are factors that can cause yield reductions, more so when gas flaring predisposes plant to severe attack by these yield-reducing agents. Odu, Adedipe \& Spiff (1976) found that tasselling of maize without cob formation and seed setting was due to the dehydrating effect of flares. In a review study, Chappelka \& Freer-Smith (1995) were of the view that apart from direct impacts by gas flares, of equal or greater importance is the potential of air pollutants to indirectly affect tree growth and vitality by predisposing them to injury from other abiotic and biotic stresses. Observation on the predisposing effects of gas flare on plants to biotic agents supports the view of Chappelka \& FreeSmith (1995).

Dry season results of plant aspect for different crops situated at various distances east of the gas flare site are presented in Table 3. Data presented in Table 3 show that plant aspect for cassava in the area was poor (2) up to a distance of $2 \mathrm{~km}$ and only fair (3) from $2.5 \mathrm{~km}$ and beyond. This was because, apart from any gas flare effect, diseases and pests heavily attacked the crop at all distances from the flare site. The diseases were cassava bacterial blight (Xanthomonas manihortis) and African cassava mosaic disease (cassava mosaic virus). The pests found on cassava were cassava mealy bug (Phenacoccus sp.) and green spider 
TABLE 3

Plant aspect for the different crops situated at various distances east of the flare site in the dry season

\begin{tabular}{|c|c|c|c|c|c|c|}
\hline \multirow{2}{*}{$\begin{array}{l}\text { Distance from } \\
\text { Flare site }(m)\end{array}$} & \multicolumn{5}{|c|}{ Plant aspect of different crops } & \multirow{2}{*}{$\begin{array}{l}\text { Distance } \\
\text { Average }\end{array}$} \\
\hline & Cassava & Plantain & Oil palm & Mango & Ватьоо & \\
\hline 500 & 2 & 3 & 3 & 4 & 4 & 3.2 \\
\hline 1000 & 2 & 3 & 4 & 4 & 5 & 3.4 \\
\hline 1500 & & 3 & & & 5 & 4.0 \\
\hline 2000 & 2 & 4 & 4 & 4 & & 3.5 \\
\hline 2500 & 3 & & & 4 & 5 & 4.0 \\
\hline 45000 (Control) & 3 & 4 & 4 & 5 & 5 & 4.2 \\
\hline Plant average & 2.4 & 3.4 & 3.8 & 4.2 & 4.8 & \\
\hline
\end{tabular}

Note: 1) Unfilled spaces mean the crop or plant was not seen in the area.

2) For the control $(45,000 \mathrm{~m}$ distance), the area sampled was increased to include the crop or plant of interest, provided it was located very far away from the gas flaring site.

mites (Mononychellus spp.). Ukegbu \& Okeke (1987) reported that chlorophyll content of cassava decreased with decreasing distance to the gas flare, and that they found a reduction in chlorophyll biosynthesis of about 35-50 per cent in leaves located about $200 \mathrm{~m}$ from the flare. The cassava plants were also reported to be distorted in growth. The slight differences in cassava plant aspect observed for the near (500-1000 $\mathrm{m}$ ) and far (2500 - $45000 \mathrm{~m}$ ) distances could only be attributed to adverse environmental factors, of which gas flaring appears to be the most prominent.

Plant aspect for plantain was only fair (3) within $1500 \mathrm{~m}$ from the gas flare. From $2000 \mathrm{~m}$ and beyond, it was good (4). Again, the difference in plant aspect can be attributed to nearness to gas flaring. Plantains grow better during the wet season since their succulent pseudostems require a lot of moisture. Expectedly, they are susceptible to desiccation during the dry season. For oil palm, the plant aspect at $500 \mathrm{~m}$ was fair (3). However, $1000 \mathrm{~m}$ and beyond, it was good (4). This difference in plant aspect scores was attributed to gas flares effects. The plant aspect for mango was good (4) from $500 \mathrm{~m}$ to $2500 \mathrm{~m}$. At the control area (45000 m) it was very good (5). There seems to be little direct impact of gas flaring on mango. Sooty mould, a common disease of mango in the area, occurs on mango at all distances from the gas flare site. Meliola mangiferae, the causal organism of sooty mould, grows superficially on leaf surface, forming a mat of mycelium. Underneath this mat of hyphae, the leaves often appear green. This explains why mango trees appear to thrive well even in the presence of the fungus, when the disease incidence is not very high.

The response of bamboo to gas flaring was similar to that of mango. Plant aspect at $500 \mathrm{~m}$ was good (4). However, from $1000 \mathrm{~m}$ and beyond it was very good (5). Here again, gas flaring seems to exact minimal direct impact (slight chlorosis) on bamboo. No infectious disease was found on bamboo. Standfield (1970) described Bambusa vulgaris, the only species of bamboo growing wild in Nigeria, as a hard woody plant with hollow stems sometimes reaching $15 \mathrm{~m}$ high and $10 \mathrm{~cm}$ in diameter. According to Purseglove (1978), bamboos usually grow gregariously in clumps; the culm of $B$. vulgaris is very strong, and that the plant has a wide ecological tolerance and can withstand severe harvesting. These are qualities that can make the bamboo withstand environmental stresses, such as high temperatures and light intensities, at the distances studied.

Based on the distance averages, it could be inferred that the distances nearest to the gas flare, 
namely $500 \mathrm{~m}$ and $1000 \mathrm{~m}$, had poorer plant aspect scores, namely 3.2 and 3.4, respectively, than the distances furthest away, namely $2500 \mathrm{~m}$ and 45,000 $\mathrm{m}$, which received plant aspect scores of 4.0 and 4.2 , respectively. This observation on the relative effects of distances from gas flare on plant aspect is not surprising since the intensity of the flare radiation, temperature, illumination, noise and gas effluents reduces as one moves further away from the flare site. Considering the plant averages, plant aspect for cassava was poorest (2.4) followed by plantain (3.4). Bamboo had the best plant as- pect performance (4.8), followed by mango (4.2). This seems to confirm Purseglove's (1978) assertion that bamboo has a wide ecological tolerance.

Results of the effects of season and relative position with respect to the gas flare on the disease severity of some host/pathogen combinations are presented in Tables $4 \mathrm{a}$ and $4 \mathrm{~b}$. Data presented in Table 4a show that within the wet season, severity of bamboo chlorosis ranged from 0 per cent at $45 \mathrm{~km}$ to 4.3 per cent at $200 \mathrm{~m}$ from the gas flare. Similarly, within the dry season, chlorosis severity ranged from 0 per cent at $45 \mathrm{~km}$ to

TABLE $4 \mathrm{a}$

Effects of location east and north-east of the flare site and season, on the severity of bamboo leaf chlorosis, expressed as weighted detransformed) means (\%)

\begin{tabular}{|c|c|c|c|}
\hline \multirow{2}{*}{$\begin{array}{l}\text { Distance from gas } \\
\text { flare }(m)\end{array}$} & \multicolumn{2}{|c|}{ Bamboo chlorosis aeverity $(\%)^{a^{*}}$} & \multirow{2}{*}{$\begin{array}{c}\text { Distance weighted } \\
\text { means }(\%)\end{array}$} \\
\hline & Wet season & Dry season & \\
\hline 200 & $4.3 \mathrm{~b}$ & $19.8 \mathrm{a}$ & $10.4 \mathrm{u}$ \\
\hline 5000 & $4.3 \mathrm{~b}$ & $4.3 \mathrm{~b}$ & $4.3 \mathrm{v}$ \\
\hline 1000 & $2.1 \mathrm{~b}$ & $4.8 \mathrm{~b}$ & $3.1 \mathrm{~W}$ \\
\hline 1500 & $\mathrm{c}$ & 0 & $\mathrm{x}$ \\
\hline 2500 & $\mathrm{c}$ & 0 & $\mathrm{x}$ \\
\hline 45000 (Control) & $\mathrm{c}$ & 0 & $\mathrm{x}$ \\
\hline Season weighted means $(\%)$ & $1.2 \mathrm{n}$ & $2.7 \mathrm{~m}$ & \\
\hline
\end{tabular}

$a^{*}$ Average of four replications. Mean separation by DMRT at $1 \%$ level. In the distance $\times$ season interaction, in the distance column and in the season row, means followed by a common letter are not significantly different at $1 \%$ level.

TABLE $4 \mathrm{~b}$

Effect of location east and north-east of the flare site and season, on the severity of sweet orange sooty mould, expressed as weighted (detransformed) means (\%)

\begin{tabular}{lccc}
\hline $\begin{array}{l}\text { Distance from gas } \\
\text { flare }(\mathrm{m})\end{array}$ & \multicolumn{2}{c}{ Bamboo chlorosis severity $(\%)^{a^{*}}$} & $\begin{array}{c}\text { Distance weighted } \\
\text { means }(\%)\end{array}$ \\
\cline { 2 - 3 } & Wet season & Dry season & $79.0 \mathrm{v}$ \\
200 & $50.0 \mathrm{~cd}$ & $97.3 \mathrm{a}$ & $64.3 \mathrm{v}$ \\
500 & $40.0 \mathrm{~d}$ & $86.6 \mathrm{~b}$ & $44.6 \mathrm{w}$ \\
1000 & $24.7 \mathrm{e}$ & $65.5 \mathrm{c}$ & $38.8 \mathrm{w}$ \\
45000 (Control) & $2.4 \mathrm{e}$ & $54.0 \mathrm{~cd}$ & $78.4 \mathrm{~m}$ \\
Season weighted means $(\%)$ & $35.7 \mathrm{n}$ &
\end{tabular}

$a^{*}$ Average of four replications. Mean separation by DMRT at $5 \%$ level. In the distance $\times$ season interaction, in the distance column and in the season row, means followed by a common letter are not significantly different at $5 \%$ level. 
about 20 per cent at $200 \mathrm{~m}$ from the flare site. The between season means of 1.2 per cent for wet and 2.7 per cent for dry season would seem to indicate that chlorosis incidence was higher in the dry season than in the wet season. However, this is mainly due to the higher incidence (19.8\%) during the dry season at $200 \mathrm{~m}$ away from the flare. The across season distance means ranged from 0 per cent at $45 \mathrm{~km}$ to 10.4 per at $200 \mathrm{~m}$ from the flare site. The trend seems to indicate that the nearer the location is to the flare site, the higher the chlorsis incidence. However, from beyond location $1500 \mathrm{~m}$ to the control site at 45,000 $\mathrm{m}$ away no bamboo chlorosis was observed.

Data presented in Table $4 \mathrm{~b}$ show that within the season, sotty mould severity on orange ranged from about 25 per cent at $45 \mathrm{~km}$ to 50 per cent at $200 \mathrm{~m}$ from the gas flare. Similarly within the dry season, sooty mould severity ranged from 54 per cent at $45 \mathrm{~km}$ to 97 per cent at $200 \mathrm{~m}$ from the flare site. The between season means of 35.7 per cent for wet and 78.4 per cent for dry season show that at 5 per cent significance level, orange sooty mould incidence was higher in the dry season than in the wet season. Each of the location $\times$ season interaction points also bears this out. The higher incidence of sooty mould during the dry season than during the wet season could be explained on the basis that the causal organism grows superficially on leaf surfaces, forming a mat of mycelial strands. These strands are easily dislodged. During heavy downpours in the rainy seson, much of the mycelial strands could be washed off the leaf surfaces, making the plants to appear greener and relatively freer from sooty mould incidence. Plants also grow more vigorously during the rainy season than in the dry season.

The across season distance means ranged from 38.8 per cent at $45 \mathrm{~km}$ to 97 per cent at $200 \mathrm{~m}$ from the flare site. The trend here also seems to indicate that the nearer the location is to flare site, the higher the sooty mould severity. However, no significant difference at the 5 per cent level was observed between locations $200 \mathrm{~m}$ and $500 \mathrm{~m}$ away from the flare site. Similarly, no significant difference was observed between locations $1000 \mathrm{~m}$ and $45 \mathrm{~km}$ from the gas flare site. These observations on the effect of gas flares on nearness of plants agree with those of other researchers, namely Odu, Adedipe \& Spiff (1976), Ukegbu \& Okeke (1987) and Dosumu \& Amadi (1996). Working on crops such as okro, maize, cowpea, soya bean and cassava, they found that the nearer plants are to gas flares, the poorer their performance. Perennial plants, such as plantain and sweet orange, also do better during the wet season than during the dry season, unless supplementary irrigation is provided in the dry seasons.

The enhanced sooty mould incidence on orange when plants are located nearer the gas flare site than when they are further away could mean that gas flaring in the area can predispose plants to higher sooty mould incidence. Gas flaring is not a causal agent of adversely the growth and vitality of trees, and so render them more susceptible to attack by the sooty mould organism. This observation bears out the findings of Chalppelka \& Freer-Smith (1995) who reported that air pollution could indirectly affect tree growth and vitality by predisposing them to injury from biotic and abiotic stresses.

\section{Conclusion}

There is some evidence to support farmers' belief that gas flaring in the study area adversely affects their crop yields. The effects are of two kinds: direct and indirect. Gas flaring induces unfavourable environmental conditions, which lowers the potentiality of plants to yield well. Indirect effects involve the predisposition of plants to higher pest and disease attacks, the attraction of yam beetles and grasshoppers to the area which attack crops, and the enhancement of some weeds which are tolerant to gas flaring. Generally, the nearer plantains and oil palms are to gas flares, the poorer is their plant aspect. Bamboo (a graminanceous plant), however, thrives well in the area. The incidence of sooty mould in orange is 
higher during the dry season than during the wet season, and also higher when located closer to the gas flares than when further away. Gas flaring tends to make orange become more susceptible to attack by the sooty mould organism. Generally, disease severity on plants was lover during the wet season than in the dry season.

Since this work is a sample survey and not a controlled experiment, there are inherent problems in trying to elucidate the effects of gas flaring on crops/plants. For example, some of the locations relative to the gas flare site were not easily accessible. What was observed in the field at the time was a culmination of several years of environmental stresses in the area. The work may not be possible to replicate in a controlled experiment because it is not possible to elucidate all the complex environmental factors at play. This includes age of perennial plants at the time gas flaring started in the area and at the time of the study. The basic assumption was made that the varieties of a given plant species respond alike to gas flaring. Gas flaring emission rate may not be steady. An oil company starting with one or two stacks may after some years increase the number to three or more. However, vegetation, particularly perennials, tend to bear for much longer the marks of environmental stresses than other organisms. This helps researchers, working at diverse places and with different plants, reaching an agreement in their field observations.

\section{References}

Anderson, B. (1996) Environmental issues and management strategies. Proceedings of 1996 International Seminar on the Petroleum Industry and Nigerian Environment.

Chappalka, A. H. \& Freer-Smith, P. H. (1995) Predisposition of Trees by Air Pollutants to Low Temperatures and Moisture Stress. Envir. Pollut. 87 (1), 105-117.

Dosumu, A. \& Amadi, B. C. (1996) Evaluation of the
Effects of Gas Flares on the Environment. Proceedings of the 1996 Annual In. Conf. Soc. of Petroleum Engineers.

Gomez, K. A. \& Gomez, A. A. (1984) Statistical procedures for agricultural research. John Wiley and Sons, NY. 680 pp.

Kadana, R. E. I. (1993) The Nigerian Gas Industry. OMPADEC Q. Rep. 1 (1), 90-96.

Last, F. T., Fowler, D. \& Freer-Smith, P. H. (1985) Effects of air pollutants on agricultural crops. Envir. Pollut. (Series A) 42, 93 - 95.

Moffat, D. \& Linden, O. (1995) Perception and Reality: Assessing Priorities for Sustainable Development in the Niger River Delta. AMBIO 24 (7/8), 527538.

Odu, C. T. I., Adedipe, N. O. \& Spiff, E. D. (1976) Determinations on the Agrono9mic Effects of Gas Flares. Tech. report (1976) submitted to Nig. Agip Oil. Co. $55 \mathrm{pp}$.

Purseglove, J. W. (1978) Tropical crops: Monocotyledons. Longman, Group Ltd, London. 607 pp.

Research and Monitoring Co-ordinating Committee (1990) The 1990 Canadian Long-Range Transport of Air Pollutants and Acid Deposition Assessment Report. Part 5 - Terrestrial effects (Pearson and Percy, ed.) $79 \mathrm{pp}$.

SNEDECoR, G. W. \& Cochran, W. G. (1980) Statistical methods. The Iowa Univ. Press, Iowa. 507 pp.

StanfiEld, D. P. (1970) The Flora of Nigeria: Grasses. Ibadan Univ. Press, Ibadan, Nigeria. 118 pp.

Steel, R. G. D. \& Torrie, J. H. (1980) Principles and procedures of statistics. Mc Graw-Hill Kogakusha Ltd., Tokyo. 633 pp.

Ukegbu, O. D. \& Okeke, A. O. (1987) Flaring of Associated Gas in the Oil Industry: Impact on Growth, Productivity and Yield of Selected Farm Crops. Proceedings of 1987 International Seminar on the Petroleum Industry and Nigerian Environment, pp. 302-311.

Walker, J. C. (1975) Plant Pathology. Tata McGrawHill Pub. Co. Ltd., New Delhi, India. 819 pp.

Wheeler, B. E. J. (1976) Diseases in crops. Edward Arnold, London. 59 pp.

WheELER, B. E. J. (1978) An introduction to plant diseases. John Wiley and Sons Ltd., london. 374 pp.

Receivd 29 Nov 2001; revised 06 Jun 2003. 